\title{
Role of p38 Mitogen-Activated Protein Kinase in Axotomy-Induced Apoptosis of Rat Retinal Ganglion Cells
}

\author{
Masashi Kikuchi, ${ }^{1,2}$ Lalitha Tenneti, ${ }^{2}$ and Stuart A. Lipton ${ }^{1,2}$ \\ ${ }^{1}$ Center for Neuroscience and Aging, The Burnham Institute, La Jolla, California 92307, and 2CNS Research Institute, \\ Brigham and Women's Hospital, Division of Neuroscience, Children's Hospital, and Program in Neuroscience, Harvard \\ Medical School, Boston, Massachusetts 02115
}

p38 is a member of the mitogen-activated protein (MAP) kinase superfamily and mediates intracellular signal transduction. Recent studies suggest that p38 is involved in apoptotic signaling in several cell types, including neurons. In the mammalian retina, $\sim 50 \%$ of the retinal ganglion cells (RGCs) die by apoptosis during development. Additionally, transection of the optic nerve close to the eye bulb causes apoptotic cell death of RGCs in adulthood. We investigated the role of p38 in axotomyinduced apoptosis of RGCs. One day after axotomy, activated (phosphorylated) p38 was visualized by immunocytochemistry in the nuclei of RGCs, but not in control retinas. Phosphorylated p38 was first detected on immunoblots $12 \mathrm{hr}$ after axotomy, reached a maximum at $1 \mathrm{~d}$, and then decreased. To investigate possible roles of p38 in RGC death, a p38 MAP kinase inhibitor, SB203580, was administered intravitreally at the time of axo-

Mitogen-activated protein (MAP) kinases are serine/threonine kinases and play an instrumental role in signal transduction from the cell surface to the nucleus. The mammalian MAP kinases can be subdivided into extracellular signal-regulated kinases (ERK), Jun N-terminal kinases (JNK), and p38 MAP kinases (p38). p38 is activated by dual phosphorylation on a Thr-Gly-Tyr motif in response to environmental stress that can also activate JNK. Such stress includes UV radiation, endotoxin, and hyperosmolarity, as well as proinflammatory cytokines like tumor necrosis factor and interleukin-1 (Freshney et al., 1994; Han et al., 1994; Lee et al., 1994; Rouse et al., 1994; Raingeaud et al., 1995). ERK is activated by mitogens and survival factors (Cano and Mahadevan, 1995; Cobb and Goldsmith, 1995). Therefore, p38 and JNK are known as stress-activated protein kinases. Recently, p38 activation has also been implicated in mediating apoptosis in several cell types in various species (Kawasaki et al., 1997; Kummer et al., 1997; Horstmann et al., 1998; Castagné and Clarke, 1999). However, the role of p38 in apoptotic pathways differs in a cell-type- and stimulation-dependent manner. In the mammalian retina, bovine retinal pigment epithelial cells manifest p38 immunoreactivity, which is activated by lipopolysaccharide or

\footnotetext{
Received Feb. 15, 2000; revised April 4, 2000; accepted April 20, 2000.

This work was supported in part by National Institutes of Health Grants R01 EY05477, R01 EY09024, and P01 HD29587 (S.A.L.), and by the Japan Eye Bank Association (M.K.). We thank Dr. Jiahuai Han of The Scripps Research Institute (La Jolla, CA) for the generous gift of anti-p38 $\beta$ antibody and recombinant p38 $\beta$ protein.

Correspondence should be addressed to Dr. Stuart A. Lipton, Center for Neuroscience and Aging, The Burnham Institute, 10901 North Torrey Pines Road, La Jolla, CA 92037. E-mail: slipton@burnham-inst.org.

Copyright (C) 2000 Society for Neuroscience $\quad 0270-6474 / 00 / 205037-08 \$ 15.00 / 0$
}

tomy and repeated at 5 and $10 \mathrm{~d}$. Assayed $14 \mathrm{~d}$ after axotomy, SB203580 increased the number of surviving RGCs in a dosedependent manner (the minimum effective concentration was $1.6 \mu \mathrm{M})$. Furthermore, MK801, a selective inhibitor of NMDA receptors, not only showed protective effects against RGC apoptosis but also attenuated p38 MAP kinase activation in a dose-dependent manner. Our findings imply that p38 is in the signaling pathway to RGC apoptosis mediated by glutamate neurotoxicity through NMDA receptors after damage to the optic nerve. p38 inhibitors could be potentially useful for the treatment of optic nerve trauma and neurodegenerative diseases that affect RGCs, such as glaucoma.

Key words: mitogen-activated protein kinase; p38; axotomy; retinal ganglion cells; apoptosis; glutamate; NMDA; optic nerve interferon- $\gamma$ (Faure et al., 1999), but the localization and role of p38 in neurons of the mammalian retina remains unclear.

In mammalian retinal ganglion cells (RGCs), as well as in other CNS neurons, axotomy close to the cell body causes retrograde degeneration and delayed RGC death (Aguayo et al., 1983; Villegas-Perez et al., 1988; Thanos et al., 1993). This form of cell death appears to be apoptotic in nature, similar to programmed cell death during retinal development (Berkelaar et al., 1994; Garcia-Valenzuela et al., 1994; Isenmann et al., 1997). It has been suggested that optic nerve-axotomized RGCs die because of deprivation of neurotrophic factors from the superior colliculus. Exogenous application of neurotrophic factors such as BDNF and NGF are known to enhance RGC survival after axotomy (Mey and Thanos, 1993; Peinado-Ramon et al., 1996; Klocker et al., 1997; Yan et al., 1999). Recently, other studies have reported that the intraocular level of glutamate is elevated after optic nerve axotomy (Yoles and Schwartz, 1998), and abnormal activation of glutamate receptors is involved in axotomy-induced RGC apoptosis (Russelakis-Carneiro et al., 1996; Yoles et al., 1997). Here we demonstrate that p38 is activated in RGCs after optic nerve axotomy and that this activation is in the signaling pathway to RGC apoptosis mediated by NMDA receptordependent neurotoxicity.

\section{MATERIALS AND METHODS}

Retrograde labeling of retinal ganglion cells. Adult male Long-Evans rats weighing 200-250 gm were obtained from a local breeder and, for all experimental manipulations, were anesthetized with $1-2 \%$ isoflurane and $70 \% \mathrm{~N}_{2} \mathrm{O}$. RGCs were retrogradely labeled with FluoroGold (hydroxystilbamidine; Molecular Probes, Eugene, OR) to allow accurate counting of cell bodies, as previously described (Vorwerk et al., 1999a,b). 
Rats were anesthetized and placed in a small stereotactic instrument. The skull was exposed and kept dry. The bregma was identified and marked, and a small window was drilled above the right hemisphere, leaving the dura intact. Using a stereotactic measuring device and a Hamilton injector, hydroxystilbamidine solution was injected into four (4) regions of the right superior colliculus using the following coordinates from the bregma (anteroposterior, mediolateral, and depth, all listed in millimeters): (1) $-5.8,+1.0,-4.4$; (2) $-6.5,+0.7,-4.0$; (3) $-6.5,+1.0$, -4.0 ; and $(4)-7.3,+1.5,-3.7$.

Axotomy. Optic nerve axotomy was performed on the left eye $4 \mathrm{~d}$ after retrograde labeling. After incision of the dorsolateral conjunctiva, the lateral extraocular muscle was transected, and the optic nerve was exposed under a stereoscopic microscope. The optic nerve was then transected at a distance of $\sim 1 \mathrm{~mm}$ from the eye bulb. During the operation, care was taken to avoid damage to the retinal blood supply.

Drug application. Intravitreal injections were performed using a 33 gauge needle attached to a $25 \mu \mathrm{l}$ syringe after pupil dilation with $1 \%$ atropine sulfate. The tip of the needle was inserted through the dorsal limbus of the eye under stereomicroscopic visualization. Injections were completed over a period of $1 \mathrm{~min}$. Intravitreal injections of SB203580 (Calbiochem, San Diego, CA), MK801 (Research Biochemicals International, Natick, MA) or control solutions (as an equal volume of saline diluent) were performed on operated eyes immediately after axotomy, and repeated 5 and $10 \mathrm{~d}$ after axotomy.

Quantification of axotomized RGC survival and histology. At various time points, rats were given an overdose of pentobarbital, and the eyes were removed. The retina was carefully dissected from the eye, prepared as a flat whole-mount in a $4 \%$ paraformaldehyde solution, and examined for stained ganglion cells by epifluorescence microscopy to determine the density. The number of surviving RGCs in experimental and control retinas was determined by counting hydroxystilbamidine-labeled neurons in three standard areas of each retinal quadrant at one-sixth, one-half, and five-sixths of the retinal radius, for a total area of $2.25 \mathrm{~mm}^{2}$, as previously described by Kermer et al. (1998). RGC survival data from each group of animals is presented as the mean density $\left(\mathrm{RGCs} / \mathrm{mm}^{2}\right)$ and SD for $n=3-6$ retinas. Statistical significance of the data were determined by an ANOVA followed by a post hoc Dunnett's test. For the histological studies, retinal whole-mounts were prepared and stained by the method of Nissl using cresyl violet $(0.1 \%)$.

Immunohistochemistry. After enucleation, the eyes were immersed in fixative composed of $4 \%$ paraformaldehyde in PBS, $\mathrm{pH} 7.4$, at $4^{\circ} \mathrm{C}$. Ten minutes later, the eyes were hemisected in the fixative, and the anterior segment, lens, and vitreous body were discarded. The remaining posterior eyecup was kept in fresh fixative solution overnight at $4^{\circ} \mathrm{C}$. The eyecup was then embedded in paraffin. Sections $5 \mu \mathrm{m}$ in thickness were cut on a microtome and transferred onto gelatin-coated glass slides. After rehydration, sections were treated for $30 \mathrm{~min}$ at room temperature with methanol to increase membrane permeability, followed by $4 \%$ hydrogen peroxide for $1 \mathrm{hr}$ to block intrinsic peroxidase activity. Then, sections were incubated with $20 \%$ normal goat serum (NGS) for $1 \mathrm{hr}$. After rinsing, the sections were incubated overnight at $4^{\circ} \mathrm{C}$ in PBS with $0.3 \%$ Triton X-100, 1\% NGS, and one of the following specific antibodies: 1:1000 anti-p38 $\alpha$ antibody (Santa Cruz Biotechnology, Santa Cruz, CA), 1:250 anti-phospho-specific p38 (New England BioLabs, Beverly, MA), or 1:50 anti-rat ED1 antibody (Serotec, Oxfordshire, UK). The sections were then incubated with biotinylated anti-IgG (Sigma, St. Louis, MO) for $2 \mathrm{hr}$ at room temperature. Color development was performed with a Vector AEC substrate kit (Vector Laboratories, Burlingame, CA) or with a Sigma Fast DAB kit. When immunoreactivity was exclusively localized to the nucleus (see Fig. $5 C$ ), counterstaining was needed to define the cell somata, and Meyer Hematoxylin was used.

Immunoblotting. Retinas were homogenized in SDS sample buffer $(2 \%$ SDS, $0.6 \%$ 2-mercaptoethanol, $10 \%$ glycerol, and $50 \mathrm{~mm}$ Tris, $\mathrm{pH} 7.2$ ) and centrifuged. After estimation of supernatant protein concentration with a Bio-Rad (Hercules, CA) Protein Assay, aliquots containing $70 \mu \mathrm{g}$ of protein were separated by SDS-PAGE and transferred onto a nitrocellulose membrane (Hybond ECL, Amersham Pharmacia Biotech). The membranes were then blocked with $25 \mathrm{~mm}$ Tris-HCl, $\mathrm{pH} 7.4,137 \mathrm{~mm}$ $\mathrm{NaCl}, 2.68 \mathrm{~mm} \mathrm{KCl}$, and $0.1 \%$ Tween 20 containing $5 \%$ nonfat milk for $1 \mathrm{hr}$ at room temperature. Membranes were probed with 1:1500 antip38 $\alpha$ antibody, 1:200 anti-p38 $\beta$ antibody (Santa Cruz Biotechnology), or 1:500 anti-phospho-specific p38 according to the instructions of the manufacturer. The antibody-reactive bands were visualized by chemiluminescent detection (ECL western detection kit; Amersham Pharmacia Biotech).
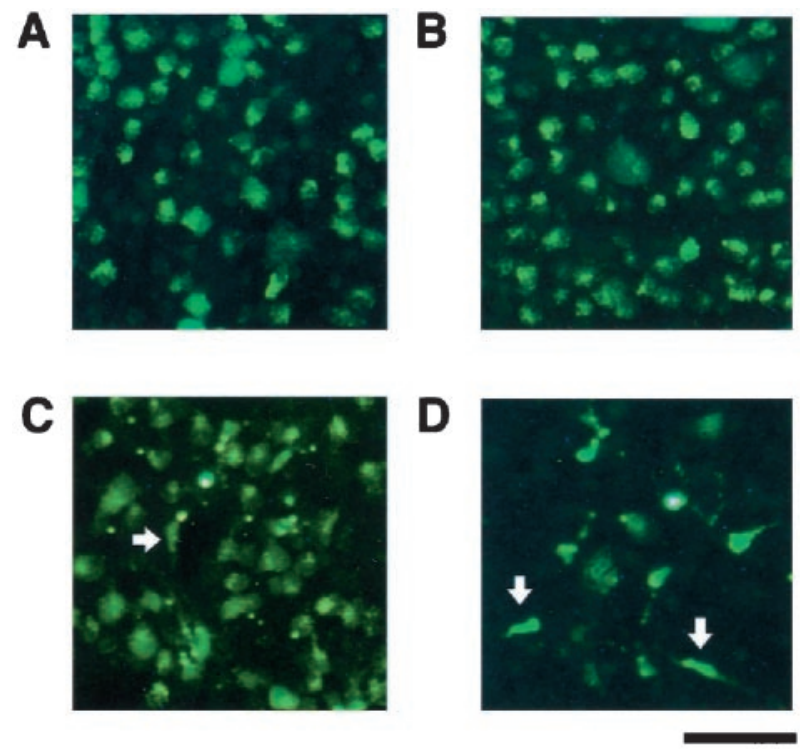

Figure 1. Representative photographs of flat-mounted retinas. Hydroxystilbamidine-labeled RGCs in corresponding regions of an unlesioned control retina $(A)$, and after axotomy at $1 \mathrm{~d}(B), 7 \mathrm{~d}(C)$, and $14 \mathrm{~d}$ $(D)$. In addition to RGCs, intensely labeled microglial cells with characteristic shapes began to appear at approximately day $7(C)$ and increased in number by day $14(D)$. Representative presumed microglial cells are marked by white arrows in $C$ and $D$. No microglial cells were labeled with hydroxystilbamidine in the control retina $(A)$ or at $1 \mathrm{~d}$ after axotomy $(B)$. Scale bar, $50 \mu \mathrm{m}$.

Retinal cell cultures. Retinal cells were prepared from 6- to 10-d-old Long-Evans rats as described previously (Leifer et al., 1984). Briefly, after dissociation in papain, retinal cells were plated on poly-L-lysinecoated glass coverslips in Eagle's minimum essential medium. RGCs were identified by immunocytochemical staining using an anti-Thy-1 antibody (2G12), which is specific among rat retinal cells for the ganglion cells (Leifer et al., 1984).

Assessment of NMDA-induced apoptosis in cultured RGCs. To induce predominantly apoptosis (Bonfoco et al., 1995; Dreyer et al., 1995), retinal cell cultures were exposed to $200 \mu \mathrm{M}$ NMDA $/ 5 \mu \mathrm{M}$ glycine for 18 $\mathrm{hr}$ in high calcium (3 mM) medium. For specific labeling of RGCs, the cultures were incubated with anti-Thy-1 antibody for $1 \mathrm{hr}$. After three washes with PBS, cells were incubated in goat anti-mouse IgG-FITC for $1 \mathrm{hr}$. For assessment of apoptosis, retinal cells were fixed, permeabilized, and stained with $20 \mu \mathrm{g} / \mathrm{ml}$ propidium iodide for $5 \mathrm{~min}$, as previously described (Ankarcrona et al., 1995). Briefly, coverslips containing the cells were washed once with PBS and permeabilized with $85 \%$ methanol for $10 \mathrm{~min}$. After another wash with PBS, coverslips were fixed in acetone for $5 \mathrm{~min}$ and subsequently stained with propidium iodide for $5 \mathrm{~min}$ in the dark. The coverslips were then mounted on glass slides in glycerol:PBS (1:1), and visualized under epifluorescence microscopy. Apoptotic nuclei were scored in cells that were also stained by anti-Thy- 1 and expressed as a fraction of total RGCs.

\section{RESULTS}

\section{Effects of axotomy on RGCs}

RGCs labeled retrogradely with hydroxystilbamidine showed a characteristically fine-dotted pattern of fluorescence in the perikarya (Fig. 1A). One day after axotomy, no remarkable change in the fluorescence pattern of RGCs was seen compared to that of controls (Fig. 1B). RGC density, as assessed by the number of fluorescently labeled cells, began to decline between 4 and $7 \mathrm{~d}$ after axotomy (Fig. $1 C$ ). By $14 \mathrm{~d}$, a substantial number of fluorescently labeled RGCs appeared to have been lost (Fig. 1D). Additionally, at 7-14 d after axotomy, we observed a number of other cells labeled with hydroxystilbamidine in the ganglion cell layer (GCL) and other retinal layers, although the pattern of 


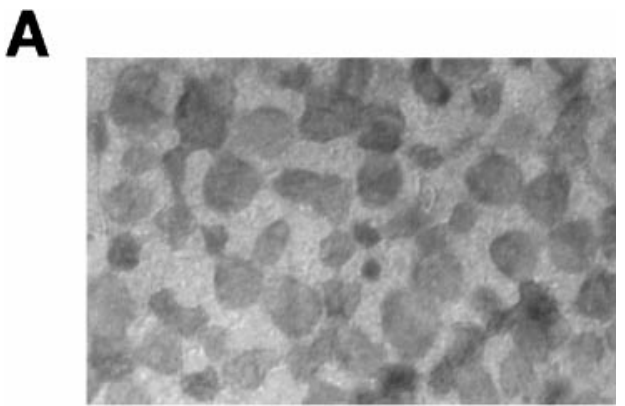

B

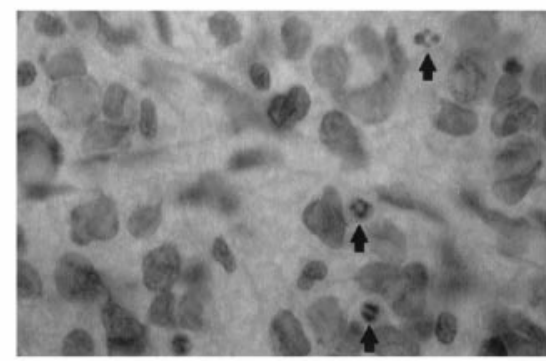

Figure 2. Photomicrographs of representative regions of the GCL in whole-mounted retinas stained with cresyl violet. Normal uninjured control retina $(A)$ versus degenerated retina $10 \mathrm{~d}$ after axotomy $(B)$. At $10 \mathrm{~d}$ after axotomy, cell density was decreased, and pyknotic nuclei (arrows) appeared in the GCL. In contrast, no pyknotic profiles were visible in the control GCL. Scale bar, $30 \mu \mathrm{m}$.

fluorescence was quite different from that of RGCs (Fig. 1C,D, white arrows). These cells had small somata and fine tortuous processes, and were morphologically typical of microglia (for specific immunostaining, see below). In the adult rat retina, microglial cells phagocytose the debris of degenerating RGCs (Perry et al., 1983) and thus can become fluorescently labeled (Thanos et al., 1992, 1993).

Morphologically, in whole-mounted retinas stained with cresyl violet, GCL of unlesioned control retinas manifest no apoptotic profiles or pyknotic nuclei (Fig. $2 A$ ). In contrast, by $10 \mathrm{~d}$ after axotomy, multiple degenerating cell bodies with pyknotic nuclei were apparent in the GCL, and the cell density in this layer appeared to be greatly diminished (Fig. 2B).

When hydroxystilbamidine fluorescence in the GCL was quantified (Fig. 3), in unlesioned control retinas the mean RGC density was $2533 \pm 104$ cells $/ \mathrm{mm}^{2}$ (mean $\pm \mathrm{SD}$ ). Within $14 \mathrm{~d}$ of axotomy, the mean RGC density decreased to $348 \pm 107$ (14\% of control, Fig. 3).

\section{Activation of p38 in RGCs after optic nerve axotomy}

We initially investigated which isoform of p38 is predominant in the adult rat retina. In control retinas, p38 $\alpha$ displayed strong immunoreactivity by immunoblotting (Fig. $4 A$, left lane), whereas p38 $\beta$ was virtually undetectable (Fig. $4 A$, lanes 2,3 ). We next used a second anti-p38 $\beta$ antibody for immunoblotting (the gift of Dr. J. Han, The Scripps Research Institute), but it, too, did not detect $\mathrm{p} 38 \beta$ immunoreactivity in control retinas or after axotomy (data not shown). Immunoblotting also revealed that p38 was not phosphorylated/activated in control retinas (Fig. 4B, top panel). Phosphorylated p38 was first detected $12 \mathrm{hr}$ after axotomy, reached a maximum at $1 \mathrm{~d}$, and then slowly decreased. By $14 \mathrm{~d}$,

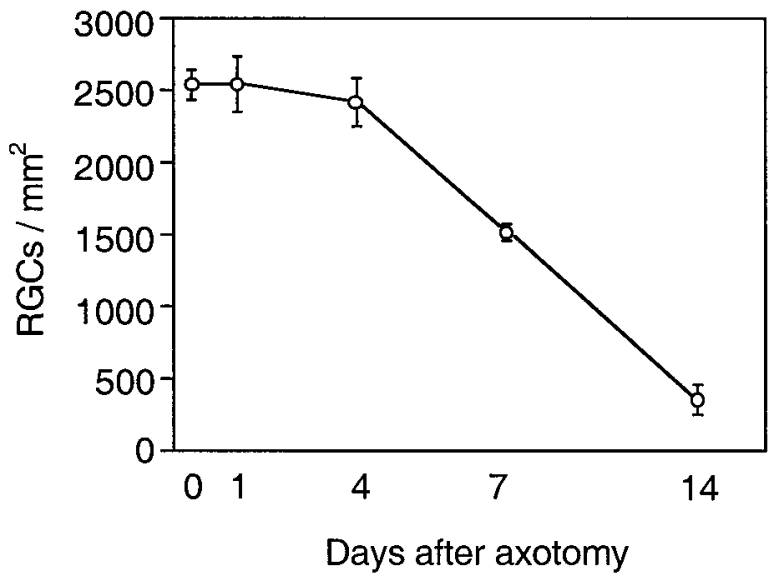

Figure 3. Effects of axotomy on the density of RGCs. Density (in cells per square millimeter; mean $\pm \mathrm{SD}$ ) of hydroxystilbamidine-labeled RGCs at different time points after axotomy: $0,1,4,7$, and $14 \mathrm{~d}(n=3-6$ retinas in each group).

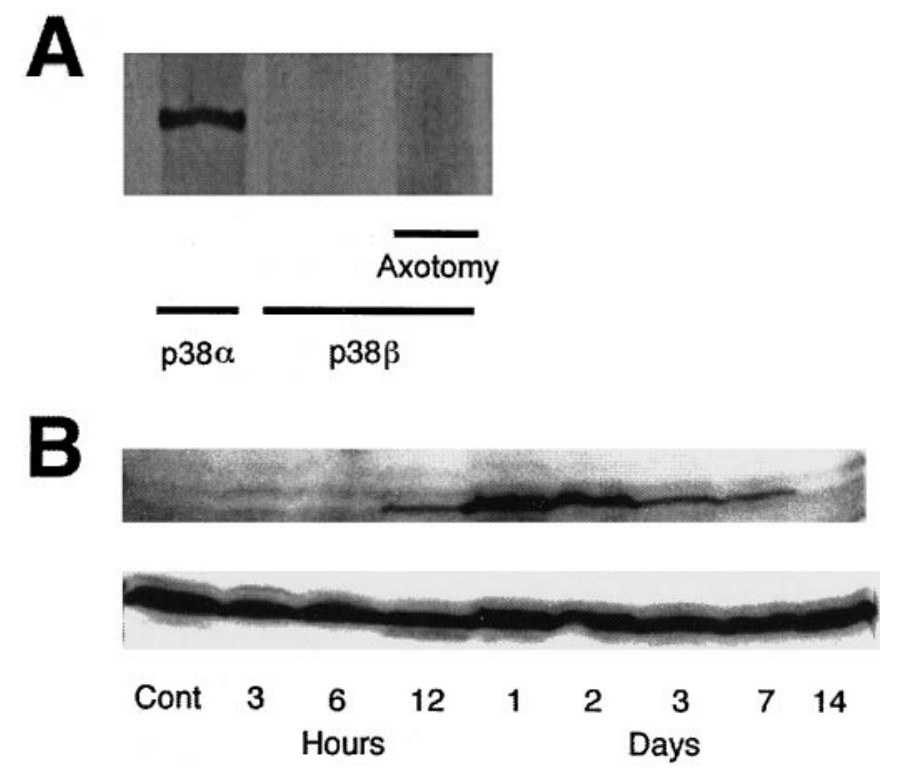

Figure 4. A, Immunoreactivity of $\mathrm{p} 38$ isoforms in adult rat retinas by immunoblotting. Strong immunoreactivity for $\mathrm{p} 38 \alpha$ was present in control retinas (left lane), whereas p38 $\beta$ was virtually undetectable in control retinas (middle lane) and $24 \mathrm{hr}$ after axotomy (right lane). B, Temporal profiles of p38 activity by immunoblotting. Total p38 $\alpha$ immunoreactivity (including both phosphorylated and nonphosphorylated forms) did not change after axotomy (bottom panel). p38 was not phosphorylated in control retinas, but phosphorylation was detected $12 \mathrm{hr}$ after axotomy and reached a maximum at $24 \mathrm{hr}$ before slowly decreasing (top panel). By $14 \mathrm{~d}$ after axotomy, phosphorylated p38 immunoreactivity had essentially disappeared.

phosphorylated p38 had virtually disappeared (Fig. 4B, top panel). Nonetheless, total p38 immunoreactivity (including both phosphorylated and unphosphorylated forms) did not change substantially after axotomy (Fig. 4B, bottom panel). This result was expected because many cell types (see below) contain unactivated (unphosphorylated) p38, and RGCs comprise only $1 \%$ of the retinal population. Importantly, $1 \mathrm{~d}$ after axotomy, when p38 phosphorylation had reached its maximum, neither RGC density nor the pattern of staining with hydroxystilbamidine had yet changed (Fig. 1B). Moreover, when phosphorylated p38 reached 
its maximum, no p38 $\beta$ immunoreactivity was observed (Fig. $4 A$, right lane), in contrast to the presence of $\mathrm{p} 38 \alpha$.

In the next series of experiments, we investigated the localization of p38 $\alpha$ and phosphorylated/activated p38 in the adult rat retina. In control retinas, p38 $\alpha$ immunoreactivity was seen in virtually all cells in the GCL, inner plexiform layer (IPL), outer plexiform layer (OPL), and in some cells in the proximal portion of the inner nuclear layer (INL; Fig. 5A, control). However, no cells in control retinas stained positively for phosphorylated/ activated p38 (Fig. 5B, control). In contrast, $1 \mathrm{~d}$ after axotomy, phosphorylated/activated p38 localized to cell nuclei in the GCL layer (Fig. 5B,C, arrows). Nonetheless, the distribution of total p38 $\alpha$ immunoreactivity did not change (Fig. 5A, 1 day). By $14 \mathrm{~d}$ after axotomy, when both phosphorylated/activated p38 immunoreactivity and most RGCs themselves were gone (Fig. 5B, 14 days), p38 $\alpha$ total immunoreactivity was still observed in the GCL, IPL, and OPL, and in some cells in the proximal portion of the INL (Fig. 5A,B, 14 days).

Previously, Walton et al. (1998) had demonstrated that microglial cells, rather than neurons, manifest p38 activation after global forebrain ischemia. Therefore, we visualized activated microglia with anti-ED1 antibody (Fig. 5D). One day after axotomy, ED1-positive cells had a different distribution compared to the p38-activated cells (Fig. 5D, black arrows). Virtually none of the microglial cells, by both histological and morphological criteria, coincided with cells that stained positively with anti-phosphorylated p38 (Fig. 5B, 1 day).

\section{Effect of p38 inhibition on survival of axotomized RGCs}

After demonstrating that $\mathrm{p} 38 \alpha$ was activated/phosphorylated in the nuclei of axotomized RGCs during an early phase of apoptosis, we next examined whether treatment with SB203580, an inhibitor of p38 (Lee et al., 1994; Cuenda et al., 1995), could prevent axotomy-induced RGC apoptosis. SB203580 was administered intravitreally at the time of axotomy and repeated at 5 and $10 \mathrm{~d}$. Assayed $14 \mathrm{~d}$ after axotomy, SB203580 increased the number of surviving RGCs in a dose-dependent manner (Fig. 6). A significant degree of neuroprotection was observed after injection of as little as $0.2 \mathrm{nmol}$ of SB203580, corresponding to an intravitreal concentration of $1.6 \mu \mathrm{M}$, given the volume of the rat vitreous has been reported to be $\sim 120 \mu$ l (Hughes, 1979).

\section{Involvement of the p38 signaling pathway in NMDA- induced neuronal apoptosis}

We next investigated if glutamate neurotoxicity via activation of the NMDA receptor could effect apoptosis via the p38 signaling pathway in RGCs. To address this question, we first examined the effects of SB203580 on NMDA-induced RGC apoptosis in vitro. Treatment with $1 \mu \mathrm{M}$ SB203580 significantly increased the survival of RGCs in the face of an NMDA exposure capable of causing apoptosis (Fig. 7). This finding suggested that p38 activation is involved in RGC apoptosis induced by NMDA. Then, we tested the effect on axotomy of the noncompetitive NMDA receptor antagonist MK801 in vivo. MK801 was injected into the vitreous in the same manner as SB203580. MK801 not only increased the number of surviving RGCs $14 \mathrm{~d}$ after axotomy (Fig. $8 A$ ), but also inhibited p38 phosphorylation/activation in a dosedependent manner (Fig. $8 B$ ). The addition of SB203580 to MK801 did not offer further protection above that of MK801 alone in this paradigm (Fig. $8 A$ ).

\section{DISCUSSION}

In the present study, we demonstrate that the p38 MAP kinase signaling pathway is involved in RGC apoptosis after axotomy. Previous reports have described the time course of survival of RGCs after axotomy (Mey and Thanos, 1993; Villegas-Perez et al., 1993; Peinado-Ramon et al., 1996; Klocker et al., 1997). In general, the loss of RGCs is more severe when the optic nerve is transected close to the eye globe (Villegas-Perez et al., 1993). In our studies we found that after axotomy near the eye, the density of RGCs remained approximately constant for $\sim 4 \mathrm{~d}$, and then $\sim 86 \%$ of RGCs died over the ensuing $10 \mathrm{~d}$. This time course is similar to that of other reports (Peinado-Ramon et al., 1996; Klocker et al., 1997; Koeberle and Ball, 1998). We next studied the time course of p38 activity after axotomy but preceding cell death.

p38 has four isoforms, designated p38 $\alpha$ (Han et al., 1994; Lee et al., 1994), p38 $\beta$ (Jiang et al., 1996), p38 $\gamma$ (Lechner et al., 1996; Li et al., 1996), and p38 (Jiang et al., 1997; Wang et al., 1997). Relatively little is known about the potential role of p38 $\gamma$ and p38 $\delta$ in apoptosis. However, p38 $\alpha$ and p38 $\beta$ have been shown to be involved in the apoptotic pathway in several cell types, including neurons, at least in vitro (Kawasaki et al., 1997; Kummer et al., 1997). Here we demonstrate strong immunoreactivity for $\mathrm{p} 38 \alpha$, but not $\mathrm{p} 38 \beta$ in the normal retina. These control retinas, however, did not manifest phosphorylated/activated p38 activity. After axotomy, anti-phospho-p38 immunoreactivity, signifying activated $\mathrm{p} 38 \alpha$, was visualized only in the GCL. Because the phosphorylated/activated p38 disappeared from the GCL as the RGCs died, it is likely that this cell type contained the activated form of $\mathrm{p} 38$.

The question arises, however, why total p38 activity did not appear to decrease in the retina after the demise of the RGCs after axotomy. In adult rats, the population of RGCs represents $<1 \%$ of total retinal cells. Additionally, $40-50 \%$ of the cells in the rodent GCL are displaced amacrine cells rather than RGCs (Perry, 1981). Fourteen days after axotomy, total p38 immunoreactivity was still seen in the GCL, IPL, OPL, and in some cells in the proximal portion of the inner nuclear layer (INL; Fig. $5 A$ ). It is likely, however, that the p38 immunoreactivity that remained 2 weeks after axotomy represented staining of amacrine cells, a population that far outnumbers the RGCs. In fact, $14 \mathrm{~d}$ after axotomy phosphorylated/activated p38 immunoreactivity had disappeared as had the RGCs. Thus, 2 weeks after axotomy total p38 immunoreactivity reflected mainly the inactive (unphosphorylated) p38 that was present in the amacrine cells. In contrast, phosphorylated/activated p38 was observed only in cells injured by axotomy, i.e., the RGCs, and only at earlier time points.

Recently, Walton et al. (1998) reported that phosphorylated p38 increases in activated microglia after forebrain ischemia. We therefore studied p38 activity in microglia in the retina. After optic nerve axotomy, microglia are known to be activated and, in our study, some became fluorescent by phagocytosis of degenerating hydroxystilbamidine-labeled RGCs (Thanos et al., 1992, 1993). However, we found that few if any microglia were labeled by anti-phospho-p38 compared to RGCs.

Next, we investigated if a p38 antagonist could protect RGCs from apoptosis after axotomy. 4-(4-fluorophenyl)-2-(4-methylsulfinylphenyl)-5-(4-pyridyl) imidazole (SB203580) is an inhibitor of p38 MAP kinase (Cuenda et al., 1995). Among the various p38 isoforms, $\mathrm{p} 38 \alpha$ and $\mathrm{p} 38 \beta$ are sensitive to this pyridinyl imidazole derivative, whereas p38 $\gamma$ and p38 $\delta$ are not (Cuenda et al., 1997). 


\section{A Anti-p38 $\alpha$}

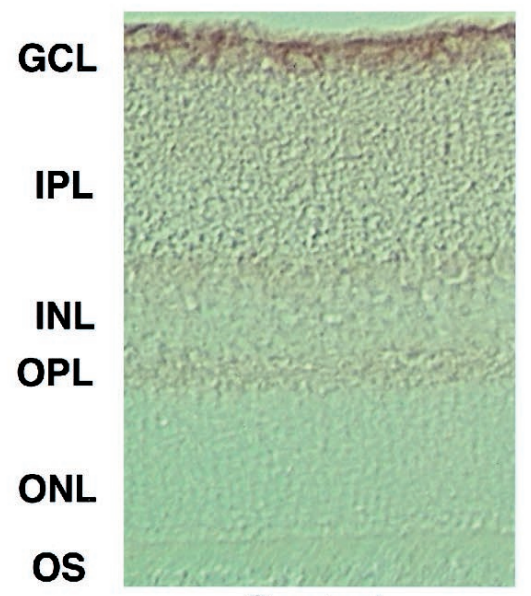

Control

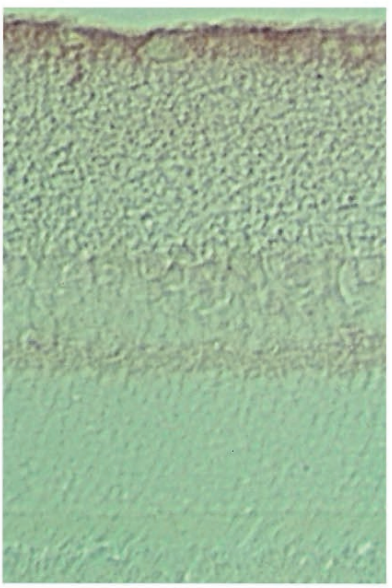

1 Day

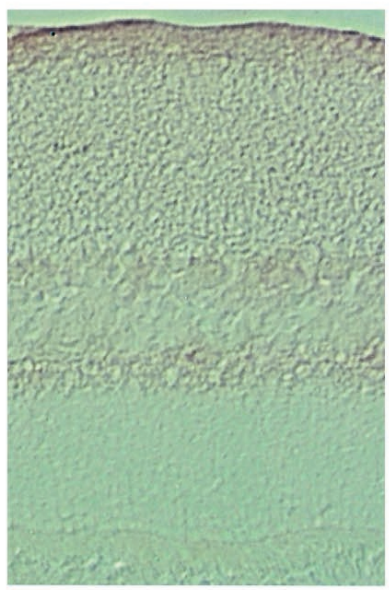

14 Days

\section{B Anti-phospho-p38}

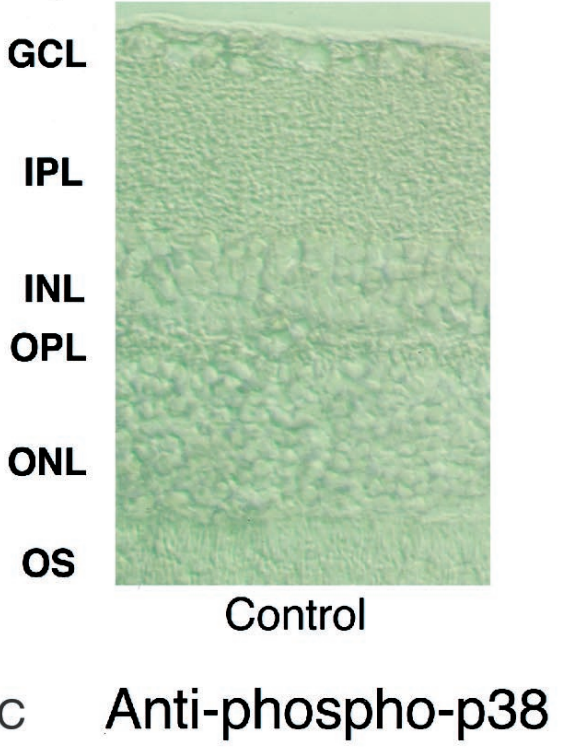

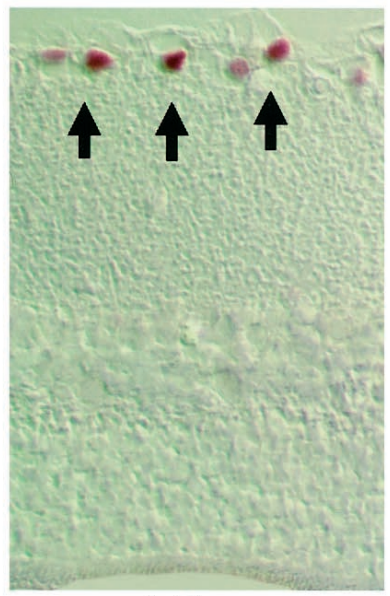

1 Day

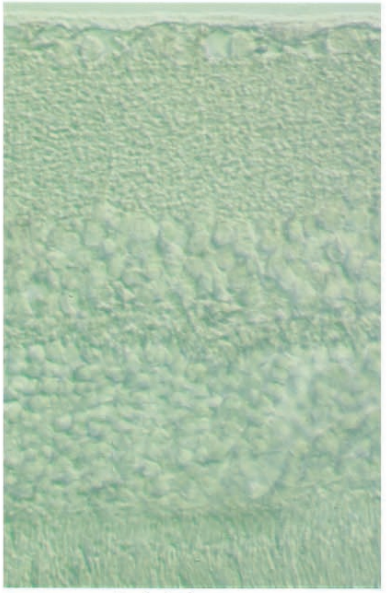

14 Days

D Anti-ED1

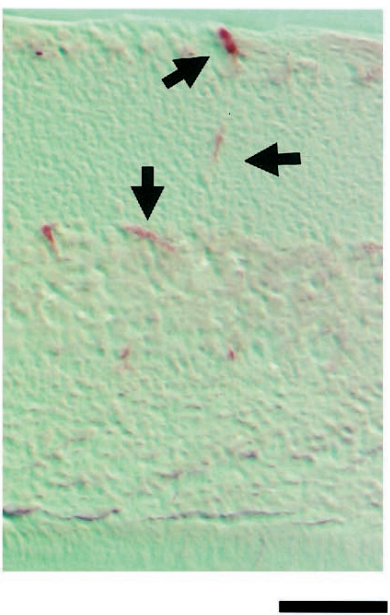

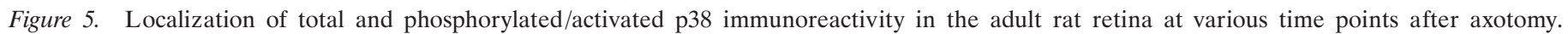

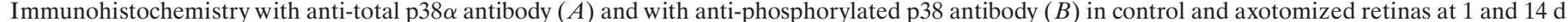

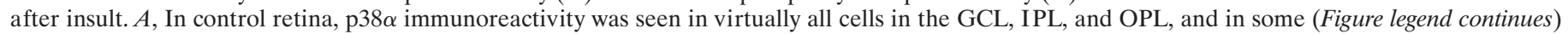




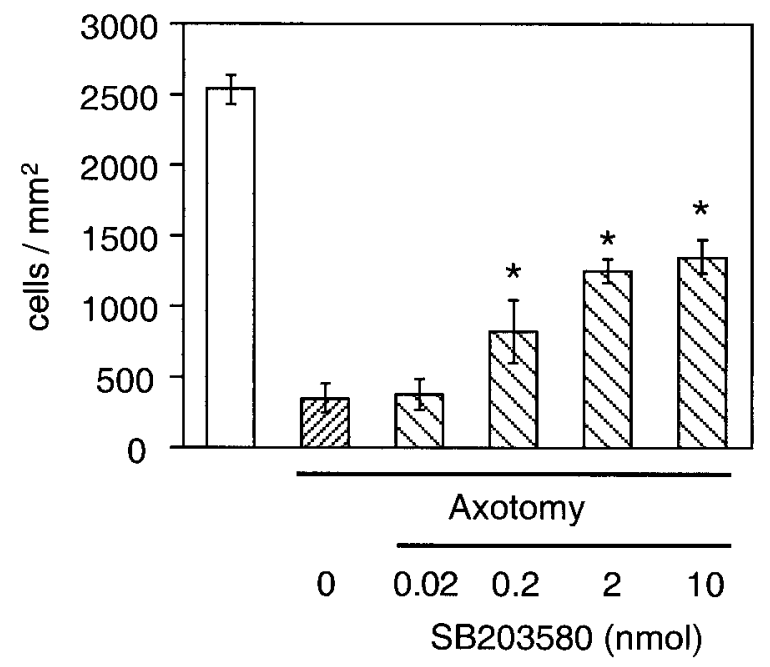

Figure 6. Quantitative assessment of the neuroprotective effect of the p38 inhibitor, SB203580. SB203580 was injected into the vitreous at the time of axotomy, injections were repeated 5 and $10 \mathrm{~d}$ later, and RGC survival was assessed $14 \mathrm{~d}$ after axotomy. At doses of $0.2 \mathrm{nmol}$ (corresponding to a concentration of $1.6 \mu \mathrm{M}$ in the vitreous) or higher, SB2030580 produced significant prevention of RGC death in the axotomy model ( ${ }^{*} p<0.01$ by ANOVA with Dunnett's post hoc comparison). Data are expressed as mean cell density \pm SD (cells per square millimeter) of hydroxystilbamidine-labeled RGCs ( $n=3-6$ retinas in each group).

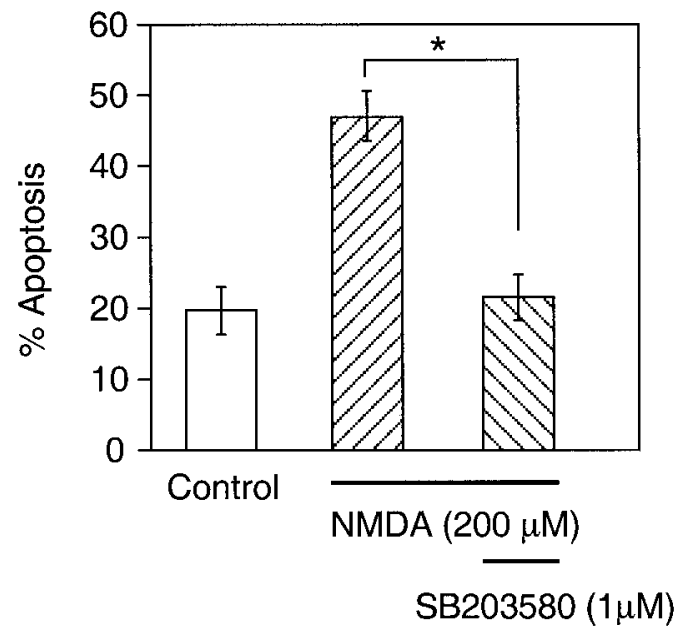

Figure 7. Inhibition of p38 activity protects cultured RGCs from NMDA-induced apoptosis. Retinal cells were either treated or not treated with $1 \mu \mathrm{M}$ SB203580 during exposure to $200 \mu \mathrm{M}$ NMDA, and treatment with SB203580 resulted in significant protection of the RGCs from apoptosis ( ${ }^{*} p<0.01$ by ANOVA with Dunnett's post hoc comparison). Data are mean \pm SEM of three independent experiments.

In general, pyridinylimidazoles, such as SB203580, inhibit p38 activity by blocking the ATP-binding site (Wilson et al., 1997). Thus, SB203580 does not inhibit the phosphorylation of p38. It is important to note that at $\sim 10$-fold higher concentrations of

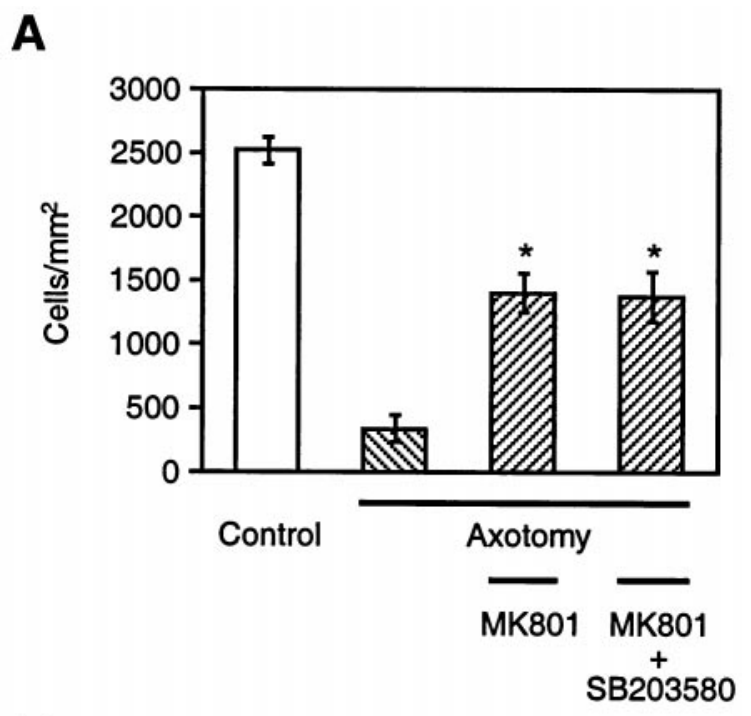

B

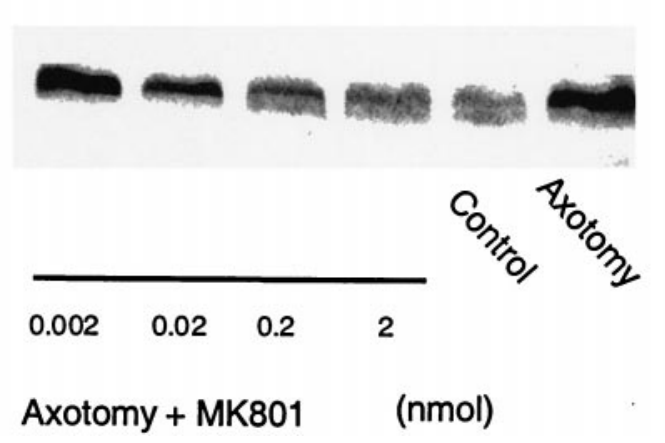

Figure 8. Effects of MK801 on p38 phosphorylation and RGC survival after axotomy. A, Protective effects of MK801 against axotomy-induced RGC apoptosis in vivo. MK801 was injected into the vitreous at the time of axotomy, and repeated injections were made 5 and $10 \mathrm{~d}$ later $(n=3-5$ retinas in each group). A dose of $2 \mathrm{nmol}$ of MK801 was administered, corresponding to an intravitreal concentration of $16 \mu \mathrm{M}$. RGC survival was assessed $14 \mathrm{~d}$ after axotomy. Data are expressed as mean cell density \pm SD (cells per square millimeter) of hydroxystilbamidine-labeled RGCs. Treatment with MK801 significantly attenuated RGC death compared to animals not receiving MK801, but the degree of protection was not enhanced by the addition of $2 \mathrm{nmol}$ of SB203580 in each injection ( ${ }^{*} p<0.01$ by ANOVA with Dunnett's post hoc comparison). B, Representative immunoblots from one of three experiments showing that the level of phosphorylated p38 observed $1 \mathrm{~d}$ after axotomy decreased with increasing concentrations of MK801.

SB203580 than used here to protect RGCs (we used $1.6 \mu \mathrm{M}$ in vivo in Fig. 6 and $1.0 \mu \mathrm{M}$ in vitro in Fig. 7), this drug can also inhibit JNK (Harada and Sugimoto, 1999). Similar to p38, JNK can also participate in apoptotic signaling in some cell types. However, at $\sim 1 \mu \mathrm{M} \mathrm{SB} 203580$ appears to be relatively specific for p38 (Harada and Sugimoto, 1999), although we acknowledge that another mode of action of the drug cannot be completely eliminated.

cells in the proximal portion of the INL. B, C, One day after axotomy, phosphorylated/activated p38 was visualized in cell nuclei in the GCL (black arrows), but not in control (nonaxotomized) retinas or in retinas $14 \mathrm{~d}$ after axotomy. Panel $C$ shows the GCL at higher magnification $1 \mathrm{~d}$ after axotomy $(400 \times)$. D , Microglial cells $1 \mathrm{~d}$ after axotomy were visualized with anti-rat ED1 antibody (black arrows). The localization and morphology of ED1-positive microglial cells were quite different from that of the phosphorylated p38-positive cells (in $B$, black arrows point to RGCs; in $D$, black arrows point to microglia). Anti-phospho-p38 antibody labeled RGCs but virtually no microglia. To better visualize this localization, counterstaining was performed in $C$ with Meyer Hematoxylin. Scale bars: $A, B, D, 75 \mu \mathrm{m} ; C, 50 \mu \mathrm{m}$. 
Additionally, we demonstrated that p38 activation/phosphorylation preceded RGC apoptosis and that pharmacological prevention of death with another drug (an NMDA receptor antagonist, see below) also prevented p38 activation/phosphorylation. Taken together, therefore, our results suggest that $\mathrm{p} 38 \alpha$ activation in RGCs occurs early after axotomy and plays an important role in apoptosis.

Next we investigated possible upstream pathways for p38 activation leading to RGC apoptosis. RGC apoptosis after optic nerve axotomy is thought to occur, at least in part, because of a lack of neurotrophic factor support from the superior colliculus (Mey and Thanos; 1993, Peinado-Ramon et al., 1996; Klocker et al., 1997; Yan et al., 1999) and also because of excessive glutamate levels possibly caused by the injury (Yoles and Schwartz, 1998). In the present study, we focused on glutamate neurotoxicity because p38 had been reported to participate in neuronal cell death pathways triggered by glutamate in in vitro cerebellar granule cell, striatal, and hippocampal models (Kawasaki et al., 1997; Vincent et al., 1998; Mukherjee et al., 1999). Additionally, RGCs were the first neurons to be shown to be vulnerable to glutamate-induced cell death (Lucas and Newhouse, 1957). Initially, we prepared cultured RGCs to test whether p38 MAP kinase activation is involved in NMDA-induced RGC apoptosis. Treatment with SB203580 protected RGCs from NMDA-induced apoptosis, suggesting that $\mathrm{p} 38$ activation plays an important role in this form of RGC death. Furthermore, intravitreal administration of the noncompetitive NMDA receptor antagonist MK801 prevented RGC apoptosis caused by axotomy in our study as well as in other reports (Russelakis-Carneiro et al., 1996; Yoles et al., 1997). Importantly, in our axotomy model, MK801 also inhibited phosphorylation of p38 in a dose-dependent manner, suggesting that p38 activation after axotomy is mediated by stimulation of NMDA receptors.

Recently, p38 inhibitors have been shown to be effective in animal models of arthritis, bone resorption, and endotoxic shock (Badger et al., 1996), and several human clinical trials are currently in progress for these entities. Optic nerve axotomy permits rapid analysis of $\mathrm{RGC}$ death and is therefore a valuable model for diseases producing RGC apoptosis, including glaucoma. We and our colleagues recently reported that glutamate neurotoxicity may mediate, at least in part, glaucomatous damage to RGCs (Dreyer et al., 1996; Dkhissi et al., 1999; Dreyer and Lipton, 1999; Vorwerk et al., 1999b). Here we show that inhibition of p38 MAP kinase activity can ameliorate glutamate-related RGC apoptosis in vitro and axotomy-induced RGC death in vivo. In fact, this represents the first in vivo model with a p38 inhibitor to show efficacy in the adult mammalian central nervous system. Therefore, we speculate that p38 inhibitors may be potentially useful for the treatment of retinal diseases such as glaucoma.

\section{REFERENCES}

Aguayo AJ, Benfey M, David S (1983) A potential for axonal regeneration in neurons of the adult mammalian nervous system. Birth Defects Orig Artic Ser 19:327-340.

Ankarcrona M, Dypbukt JM, Bonfoco E, Zhivotovsky B, Orrenius S, Lipton SA, Nicotera P (1995) Glutamate-induced neuronal death: a succession of necrosis or apoptosis depending on mitochondrial function. Neuron 15:961-973.

Badger AM, Bradbeer JN, Votta B, Lee JC, Adams JL, Griswold DE (1996) Pharmacological profile of SB 203580, a selective inhibitor of cytokine suppressive binding protein/p38 kinase, in animal models of arthritis, bone resorption, endotoxin shock and immune function. J Pharmacol Exp Ther 279:1453-1461.

Berkelaar M, Clarke DB, Wang YC, Bray GM, Aguayo AJ (1994) Axo- tomy results in delayed death and apoptosis of retinal ganglion cells in adult rats. J Neurosci 14:4368-4374.

Bonfoco E, Krainc D, Ankarcrona M, Nicotera P, Lipton SA (1995) Apoptosis and necrosis: two distinct events induced, respectively, by mild and intense insults with $N$-methyl-D-aspartate or nitric oxide/ superoxide in cortical cell cultures. Proc Natl Acad Sci USA 92:7162-7166.

Cano E, Mahadevan LC (1995) Parallel signal processing among mammalian MAPKs. Trends Biochem Sci 20:117-122.

Castagné, Clarke PGH (1999) Inhibition of mitogen-activated protein kinases protect axotomized developing neurons. Brain Res 842:215-219.

Cobb MH, Goldsmith EJ (1995) How MAP kinases are regulated. J Biol Chem 270:14843-14846.

Cuenda A, Rouse J, Doza YN, Meier R, Cohen P, Gallagher TF, Young PR, Lee JC (1995) SB 203580 is a specific inhibitor of a MAP kinase homologue which is stimulated by cellular stresses and interleukin-1. FEBS Lett 364:229-233.

Cuenda A, Cohen P, Buee-Scherrer V, Goedert M (1997) Activation of stress-activated protein kinase-3 (SAPK3) by cytokines and cellular stresses is mediated via SAPKK3 (MKK6); comparison of the specificities of SAPK3 and SAPK2 (RK/p38). EMBO J 16:295-305.

Dkhissi O, Chanut E, Wasowicz M, Savoldelli M, Nguyen-Legros J, Minvielle F, Versaux-Botteri C (1999) Retinal TUNEL-positive cells and high glutamate levels in vitreous humor of mutant quail with a glaucoma-like disorder. Invest Ophthalmol Vis Sci 40:990-995.

Dreyer EB, Lipton SA (1999) New perspectives on glaucoma. JAMA 281:306-308.

Dreyer EB, Zhang D, Lipton SA (1995) Transcriptional or translational inhibition blocks low dose NMDA-mediated cell death. NeuroReport 6:942-944.

Dreyer EB, Zurakowski D, Schumer RA, Podos SM, Lipton SA (1996) Elevated glutamate levels in the vitreous body of humans and monkeys with glaucoma. Arch Ophthalmol 114:299-305.

Faure V, Hecquet C, Courtois Y, Goureau O (1999) Role of interferon regulatory factor- 1 and mitogen-activated protein kinase pathways in the induction of nitric oxide synthase-2 in retinal pigmented epithelial cells. J Biol Chem 274:4794-4800.

Freshney NW, Rawlinson L, Guesdon F, Jones E, Cowley S, Hsuan J, Saklatvala J (1994) Interleukin-1 activates a novel protein kinase cascade that results in the phosphorylation of Hsp27. Cell 78:1039-1049.

Garcia-Valenzuela E, Gorczyca W, Darzynkiewicz Z, Sharma SC (1994) Apoptosis in adult retinal ganglion cells after axotomy. J Neurobiol 25:431-438.

Han J, Lee JD, Bibbs L, Ulevitch RJ (1994) A MAP kinase targeted by endotoxin and hyperosmolarity in mammalian cells. Science 265:808-811.

Harada J, Sugimoto M (1999) An inhibitor of p38 and JNK MAP kinases prevents activation of caspase and apoptosis of cultured cerebellar granule neurons. Jpn J Pharmacol 79:369-378.

Horstmann S, Kahle PJ, Borasio GD (1998) Inhibitors of p38 mitogenactivated protein kinase promote neuronal survival in vitro. J Neurosci Res 52:483-490.

Hughes A (1979) A schematic eye for the rat. Vision Res 19:569-588.

Isenmann S, Wahl C, Krajewski S, Reed JC, Bähr M (1997) Upregulation of Bax protein in degenerating retinal ganglion cells precedes apoptotic cell death after optic nerve lesion in the rat. Eur J Neurosci 9:1763-1772.

Jiang Y, Chen C, Li Z, Guo W, Gegner JA, Lin S, Han J (1996) Characterization of the structure and function of a new mitogenactivated protein kinase (p38beta). J Biol Chem 271:17920-17926.

Jiang Y, Gram H, Zhao M, New L, Gu J, Feng L, Di Padova F, Ulevitch RJ, Han J (1997) Characterization of the structure and function of the fourth member of p38 group mitogen-activated protein kinases, p38delta. J Biol Chem 272:30122-30128.

Kawasaki H, Morooka T, Shimohama S, Kimura J, Hirano T, Gotoh Y, Nishida E (1997) Activation and involvement of p38 mitogenactivated protein kinase in glutamate-induced apoptosis in rat cerebellar granule cells. J Biol Chem 272:18518-18521.

Kermer P, Klocker N, Labes M, Bähr M (1998) Inhibition of CPP32-like proteases rescues axotomized retinal ganglion cells from secondary cell death in vivo. J Neurosci 18:4656-4662.

Klocker N, Braunling F, Isenmann S, Bähr M (1997) In vivo neurotrophic effects of GDNF on axotomized retinal ganglion cells. NeuroReport 8:3439-3442. 
Koeberle PD, Ball AK (1998) Effects of GDNF on retinal ganglion cell survival following axotomy. Vision Res 38:1505-1515.

Kummer JL, Rao PK, Heidenreich KA (1997) Apoptosis induced by withdrawal of trophic factors is mediated by p38 mitogen-activated protein kinase. J Biol Chem 272:20490-20494.

Lechner C, Zahalka MA, Giot JF, Moller NP, Ullrich A (1996) ERK6, a mitogen-activated protein kinase involved in $\mathrm{C} 2 \mathrm{C} 12$ myoblast differentiation. Proc Natl Acad Sci USA 93:4355-4359.

Lee JC, Laydon JT, McDonnell PC, Gallagher TF, Kumar S, Green D, McNulty D, Blumenthal MJ, Heys JR, Landvatter SW, Stricker JE, McLaughlin MM, Siemens IR, Fisher SM, Livi GP, White JR, Adams JL, Young PR (1994) A protein kinase involved in the regulation of inflammatory cytokine biosynthesis. Nature 372:739-746.

Leifer D, Lipton SA, Barnstable CJ, Masland RH (1984) Monoclonal antibody to Thy- 1 enhances regeneration of processes by rat retinal ganglion cells in culture. Science 224:303-306.

Li Z, Jiang Y, Ulevitch RJ, Han J (1996) The primary structure of p38 gamma: a new member of $\mathrm{p} 38$ group of MAP kinases. Biochem Biophys Res Commun 228:334-340.

Lucas DR, Newhouse JP (1957) The toxic effect of sodium l-glutamate on the inner layers of the retina. Arch Ophthalmol 58:193-201.

Mey J, Thanos S (1993) Intravitreal injections of neurotrophic factors support the survival of axotomized retinal ganglion cells in adult rats in vivo. Brain Res 602:304-317.

Mukherjee PK, DeCoster MA, Campbell FZ, Davis RJ, Bazan NG (1999) Glutamate receptor signaling interplay modulates stresssensitive mitogen-activated protein kinases and neuronal cell death. J Biol Chem 274:6493-6498.

Peinado-Ramon P, Salvador M, Villegas-Perez MP, Vidal-Sanz M (1996) Effects of axotomy and intraocular administration of NT-4, NT-3, and brain-derived neurotrophic factor on the survival of adult rat retinal ganglion cells. A quantitative in vivo study. Invest Ophthalmol Vis Sci 37:489-500.

Perry VH (1981) Evidence for an amacrine cell system in the ganglion cell layer of the rat retina. Neuroscience 6:931-944.

Perry VH, Henderson Z, Linden R (1983) Postnatal changes in retinal ganglion cell and optic axon populations in the pigmented rat. J Comp Neurol 219:356-368.

Raingeaud J, Gupta S, Rogers JS, Dickens M, Han J, Ulevitch RJ, Davis RJ (1995) Pro-inflammatory cytokines and environmental stress cause p38 mitogen- activated protein kinase activation by dual phosphorylation on tyrosine and threonine. J Biol Chem 270:7420-7426.

Rouse J, Cohen P, Trigon S, Morange M, Alonso-Llamazares A, Zamanillo D, Hunt T, Nebreda AR (1994) A novel kinase cascade triggered by stress and heat shock that stimulates MAPKAP kinase- 2 and phosphorylation of the small heat shock proteins. Cell 78:1027-1037.
Russelakis-Carneiro M, Silveira LC, Perry VH (1996) Factors affecting the survival of cat retinal ganglion cells after optic nerve injury. J Neurocytol 25:393-402.

Thanos S, Mey J, Wild M (1993) Treatment of the adult retina with microglia-suppressing factors retards axotomy-induced neuronal degradation and enhances axonal regeneration in vivo and in vitro. $\mathbf{J}$ Neurosci 13:455-466.

Thanos S, Pavlidis C, Mey J, Thiel HJ (1992) Specific transcellular staining of microglia in the adult rat after traumatic degeneration of carbocyanine-filled retinal ganglion cells. Exp Eye Res 55:101-117.

Villegas-Perez MP, Vidal-Sanz M, Bray GM, Aguayo AJ (1988) Influences of peripheral nerve grafts on the survival and regrowth of axotomized retinal ganglion cells in adult rats. J Neurosci 8:265-280.

Villegas-Perez MP, Vidal-Sanz M, Rasminsky M, Bray GM, Aguayo AJ (1993) Rapid and protracted phases of retinal ganglion cell loss follow axotomy in the optic nerve of adult rats. J Neurobiol 24:23-36.

Vincent SR, Sebben M, Dumuis A, Bockaert J (1998) Neurotransmitter regulation of MAP kinase signaling in striatal neurons in primary culture. Synapse 29:29-36.

Vorwerk CK, Simon P, Gorla M, Katowitz W, Zurakowski D, Levin LA, Dreyer EB (1999a) Pilocarpine toxicity in retinal ganglion cells. Invest Ophthalmol Vis Sci 40:813-816.

Vorwerk CK, Gorla MS, Dreyer EB (1999b) An experimental basis for implicating excitotoxicity in glaucomatous optic neuropathy. Surv Ophthalmol S142-S150.

Walton KM, DiRocco R, Bartlett BA, Koury E, Marcy VR, Jarvis B, Schaefer EM, Bhat RV (1998) Activation of p38 MAPK in microglia after ischemia. J Neurochem 70:1764-1767.

Wang XS, Diener K, Manthey CL, Wang S, Rosenzweig B, Bray J, Delaney J, Cole CN, Chan-Hui PY, Mantlo N, Lichenstein HS, Zukowski M, Yao Z (1997) Molecular cloning and characterization of a novel p38 mitogen-activated protein kinase. J Biol Chem 272:23668-23674.

Wilson KP, McCaffrey PG, Hsiao K, Pazhanisamy S, Galullo V, Bemis GW, Fitzgibbon MJ, Caron PR, Murcko MA, Su MS (1997) The structural basis for the specificity of pyridinylimidazole inhibitors of p38 MAP kinase. Chem Biol 4:423-431.

Yan Q, Wang J, Matheson CR, Urich JL (1999) Glial cell line-derived neurotrophic factor (GDNF) promotes the survival of axotomized retinal ganglion cells in adult rats: comparison to and combination with brain-derived neurotrophic factor (BDNF). J Neurobiol 38:382-390.

Yoles E, Schwartz M (1998) Elevation of intraocular glutamate levels in rats with partial lesion of the optic nerve. Arch Ophthalmol 116:906-910.

Yoles E, Muller S, Schwartz M (1997) NMDA-receptor antagonist protects neurons from secondary degeneration after partial optic nerve crush. J Neurotrauma 14:665-675. 